\title{
Contextual American Transcendentalism
}

\author{
Alireza Manzari \\ English Department, Islamic Azad University- Mashhad Branch, Iran \\ Email: alireza_manzari@yahoo.com
}

\begin{abstract}
As an outstanding political, philosophical, and literary movement, American Transcendentalism grew during the first half of Nineteenth century. What Transcendentalists believed in was a bond between God and the world, and that God is the origin of everything in nature. Also, God can be found in everything including the soul of every human being which is the place for divinity. The Transcendentalists believed in the oneness of God which is apparent in all religious traditions; they contended if every person has a Divine reason, so he must be free to realize his fullest capacity; in that case the realization of Heaven and Hell would be possible. This article tries to have a closer look at American Transcendental movement in social, philosophical and religious, and literary contexts.
\end{abstract}

Index Terms-Transcendentalism, social context, philosophical-religious context, literary context, American literature

\section{INTRODUCTION}

For the Transcendentalists, a direct relationship with God and nature was of great importance. In his essay, 'Nature", Ralph Waldo Emerson (2008) wrote: "The foregoing generations beheld God and Nature face to face; we- through their eyes. Why should not we also enjoy an original relation to the universe?" (P. 38) What Transcendentalists wanted to reclaim was the divine, mystical, and supernatural light bestowed upon human soul by the spirit of God. They regarded the free development of individual emotions as the only solution to human problems.

For the Transcendentalists, the world of spirits is the only source for reality. A person sees only appearances, which are transient reflections of the world of the spirit, in the existing physical world. The only way for the people to learn about the physical world is through their senses and understanding. They learn about the world of spirit through another power, called reason by which they meant insight. For them reason or insight was nothing but an independent and intuitive ability to distinguish the absolute truth. In his "An Essay on Transcendentalism", Charles Mayo Ellis (1970) expressed: "That belief we term Transcendentalism which maintains that man has ideas, that come not through the five senses or the powers of reasoning; but are either the result of direct revelation from God, his immediate inspiration, or his immanent presence in the spiritual world... ." (P. 23)

As a leading proponent of American Transcendentalism, Ralph Waldo Emerson thought that the spiritual world is primary in comparison to the physical world, which regarded as the secondary. He believed that the physical world through making humans aware of its beauty and providing useful goods serves human beings. What Emerson and his followers believed was that human beings find truth within themselves; for them self reliance and individuality were of prime importance, and so were individuality, a strong connection with nature, beauty and God. Jerry Phillips (2010) in his book "Romanticism and Transcendentalism" mentioned:

"Emerson's romantic philosophy is most clearly seen in his work, Nature (1836). In Nature, Emerson describes a world in which nearly everything in it is a symbol of the spirit. For Emerson, nature is the material world, everything that exists outside the self. This world is one-half, a cover over a greater realm, the spirit or Soul" (P. 52).

Transcendentalists believed that for a person to be able to distinguish what is right from what wrong, he should ignore social customs and principles and rely only on reason (insight). Emerson emphasized on his "Two Truth" theory of knowledge - Understanding and Reason in which the former means the empirical truth and the latter, refers to the absolute truth transcending sense, experience and directly perceived by intuition. In his book, "Introduction to Metaphysic" Henri Bergson (2007) wrote about the differences between these two deeply different approaches to knowing:

"The first implies that we move round the object; the second that we inter into it. The first depends on the point of view at which we are placed and on the symbols by which we express ourselves. The second neither depends on a point of view, nor relies on any symbol. The first kind of knowledge may be said to stop at the relative, the second, in those cases where it is possible, to attain the absolute" (P. 44).

Transcendentalists regarded the doctrine and organized churches of orthodox Christianity as interfering with personal relationship of man with his God. What they emphasized was a rejection of the authority of Christianity and gaining knowledge of God through insight. Transcendentalists believed that all people were equal in the eyes of God, and all had sufficient spiritual power to intuit God in their daily lives (Phillips, 2010). American Transcendentalism believed in the existence of God within every creature and the importance of intuitive thought. It was based "a monism holding to the unity of the world and God, and immanence of God in the world" (Hart, 1995, P.770). One of Emerson's 
transcendentalist followers drew an amazing picture of his master as a lucid eyeball: his skinny little body is topped with a huge eyeball instead of a head, the optic nerve tied into a ponytail behind. The eyeball with legs wears tails and a hat (Stula, 1999).

Ralph Waldo Emerson in his essays, "Nature" (1836), "Self- Reliance" and "Over soul" (both 1841), and Henry David Thoreau in his book, "Walden" (1854) expressed the basic ideas underlying transcendentalism which regarded nature not only as beautiful, but as a reflection of divinity, which is literally the face of God. Leslie Perrin Wilson (2000) noted "above all the Transcendentalists believed in the importance of a direct relationship with God and with nature" (P.4). For them "macrocosm" (the universe) and the "microcosm" (the individual) were in direct connection with each other. They both also took hold of all animate and inanimate objects, and the divine as well.

They believed that Nature represented all of humankind as well as God, and also they stated that much could be learned through a careful examination of the minute elements of nature as microcosms of the larger world (Felton, 2006 , P. 120). Also the union with the "Over-soul", which was regarded as reflected in everything in the world, was claimed to be the purpose of human life. According to the Transcendentalists, people could develop their capacity by submersing themselves in the beauty of the natural world. They were only the beauty and truth which could be experienced through intuition, though careful observation of nature might help to uncover its laws. They also identified the soul of each individual as similar with that of the world and it contained what the world contained. So, Transcendentalism emerged as a religious movement. In his "Nature", Emerson (2008) stated: "I become a transparent eye-ball. I am nothing. I see all. The currents of the Universal Being circulate through me; I am part or parcel of God." (P. 38)

\section{SOCIAL CONTEXT}

Many reform movements occurred during the nineteenth century. These were attempts to change certain ways of things. Of these, three major movements altered the nation, namely: The abolitionist movement, the temperance movement, and the women's suffrage movement. One other important social movement in the history of the United States of America was antislavery movement. To the followers of Transcendentalism, slavery was inherently wrong, because it stood in the way of the spiritual development of the slaves. Transcendentalists protested against slavery in a number of different ways and even some of them, most notably Parker, played a leading role in the abolitionist movement.

Henry David Thoreau (2004) proclaimed that it was the duty of every person to act against the state where he feels that it is morally wrong. He also noted that "under a government which imprisons any unjustly, the true place for a just man is also a prison" (P. 78). He did not reject politics in general, but asked the state to act in harmony with the moral principles.

He declared: "I ask for, not at once no government, but at once a better government" (Gross, 2005, P. 8). It was in 1849 that Henry David Thoreau published his famous article proposing his views on government. In that article he outlined the duties of the individuals to government which he called "Resistance to Civil Government" (Gross, 2005 , P. 8).

The Transcendentalists' emphasis on the importance of individual was also revealed in their attitudes towards slavery in which the slaves were deprived of their basic rights including their right of choice regarding their way of living. For the Transcendentalists, including Emerson, it was unacceptable that an individual could be allowed to lawfully buy or sell another individual and dominate his life thoroughly. Henry Thoreau and Waldo Emerson supported the removal of the slavery. Dr. William Ellery Channing (2012), the father of Unitarianism, who acted as a source of inspiration to that movement, in his essay titled "Slavery", favored abolition. He declared: "The deliberate, solemn conviction of good men through the world, that slavery is a grievous wrong to human nature, will make itself felt. To increase this moral power is every man's duty. To embody and express this great truth is in every man's power; and thus every man can do something to break the chain of the slave" (P. 35).

The reform of the society through perfection of the individuals from within and not from without through external means, was what Transcendentalists emphasized. The ideas that Thoreau proposed in his essay had been structured through his New England heritage and the events of his time. Walter Harding (1989) in his book notes: "Thoreau grew up in an atmosphere of anti-slavery feelings. His mother and sisters were influenced by some abolitionist boarders to join an anti-slavery society. The Thoreau family became very active in that society and was well known in the community as abolitionists" (P. 180).

Thoreau (2011) was once arrested, while living in Poland for not having paid his tax. He believed he had never been attacked except by the government and that "wherever a man goes, men will pursue and paw him with their dirty institutions..." (P. 30). It is moral to break a law, Thoreau (2011) concluded, if that law "requires you to be the agent of injustice to another..." (P. 30). In other words, if a government changes to become unjust or oppressive, it would be the duty of everyone to resist it, at first peacefully but, if necessary, with through the enforcement of force and violence. He noted, "This people must cease to hold slaves, and to make war on Mexico, though it cost them their existence as a people" (Thoreau, 2011P. 30). Henry David Thoreau (2011) believed in the capacity of a determined morally minded minority to correct the evils of the majority. He continued: "I know this well, that if one thousand, if one hundred, if ten men whom I could name--if ten honest men only--ay, if one HONEST man, in this state of Massachusetts, ceasing to 
hold slaves, were actually to withdraw from this co partnership (with the government) and be Locked up in the country jail therefore, it would be the abolition of slavery in America. For it matters not how small the beginning may seem to be, what is once well done is done forever. But we love better to talk about it" (P. 30).

The political, economic, and social roles played by women changed greatly through pre- Revolutionary time to the early twentieth century. In the years leading up to the American Revolution, women were viewed as "subordinate to males" and were therefore subject to the laws and regulations imposed upon them by men (Donald, 1960). They were expected to get married, have children, and do as right doing wives and mothers. Because of the masculine society in which they were living, women usually were not entitled to many of their legal rights, including suffrage or property (Lindenmeyer, 2000).

One of the journalist, critics, and women's right activists whose name is associated with The American Transcendentalism is Margaret Fuller. What Fuller believed and emphasized was everybody's right to be let develop a full capacity of their nature. Transcendentalists including Emerson regarded the process of self- cultivation as a central value; this idea was the basis upon which Fuller based her argumentation for women's right. She believed in the policy of "All man and women are created equal" which was a revelation of support for women's right and it produced a very big wave of optimism. Fuller (2009) wrote:

"He regarded [women] as souls, each of which had a destiny of its own, incalculable to other minds, and whose leading it must follow, guided by the light of a private conscience.... Thus all beings were treated by him with an equal, and sweet, though solemn courtesy" (P. 72).

Between 1838 and 1844 she managed some "conversation" classes for women in literature, education, mythology, and philosophy. In 1845, Margaret Fuller published her book in feminism entitles "Women in the Nineteenth century", as a demand for political equality and a plea for emotional, spiritual, and intellectual improvement of women's status. She wrote after finishing the book: "I had put a good deal of my true self in it, as if, I suppose I went away now, the measure of my footprint would be left on earth" ( Bean, 2000, P. 320). Fuller (2009) tried to obtain suffrage right and the right to extra- domestic activities for women. She believed that women had to define themselves not in relation to men, but to God. In her book" Women in the Nineteenth century" she expressed:

"I would have woman lay aside all thought, such as she habitually cherishes, of being taught and led by men. I would have her, like the Indian girl, dedicate Herself to the Sun, the sun of Truth, and go nowhere if this beams did not clear the path" (P.72).

Although women did not get the suffrage right till 1920, the movement for women's right developed out of this abolitionist movement. It was a period which witnessed some efforts to improve social treatment with the poor, the mentally ill, to improve general education and to end drinking. In 1846, as a correspondent for the New York Tribune, Margaret Fuller took a trip to Europe. "Fuller's Tribune writing illustrates the potential service of the critic as mediator in a pluralistic, cosmopolitan, literary culture" (Bean, 2000, P.320).Suffrage was a social and political issue in the western areas of The United States. It was viewed "as a practical movement" in the west where women were entitled more freedom practically than their counterparts in the East (Donald, 1960). In Kansas there was an effort to allow women's suffrage as well as to "ensure the enfranchising of black males" (Banner, 1980, P.88).

The third movement under our attention is The Temperance movement. Religious grounds had an opposite called "Demon Rum" which defiled "The body as a temple" as the Scriptures say, and let to immoral activities. During this time, Alcoholism was an important issue it had a great effect on the family budget and often caused safety dangers for industrial workers.

Transcendentalists viewed a link between alcoholism and poverty which caused the establishment of a number of organizations to fight the demons including, The American Temperance Union. As a result many laws were enacted to restrict and, finally ban the sale of alcoholic drinks in many States. Daniel Sutherland (1989) expressed that "The temperance movement, gained momentum in the years surrounding the Civil War, and the Woman's Christian Temperance Union (WCTU) was founded as a means to prohibit men from consuming alcohol in excess quantities." (P. 94).

\section{PhilosophicAl And Religious Contexts}

Plato was the first person who proposed the concept of Transcendentalism. He believed in the absolute goodness, the one beyond description. This goodness, according to him, could be perceived only through intuition and insight, instead of logic or rationality. An important aspect of Plato's idea is that he believed in the ability of man to know the mere being in itself. For him the reason was that we are not strangers to the ground of our being. Ralph Waldo Emerson, later, used other Plato's theory that the world is an expression of spirit to improve the theory of correspondence.

John Locke believed that human mind was devoid of conscience at birth. It lacked also moral understanding, intuition, and all that might develop through experience. He rejected the theory of innateness of Belief in God and moral law. For Locke, the process through which religious and moral concepts are internalized were equal with those processes by which mathematics and other branches of science are taken in; as well, religious perception was necessarily a material, and not an idealistic process which did not transcend the physical world. American Unitarians used Locke's' ideas of Rationalism as they tried to put the negative view of man and nature held by their Calvinistic predecessors aside. Locke's materialism rejected transcendentalist views as they were trying to define religious understanding. 
Transcendentalists were more eager to hold a more idealistic view of human mind and mental capacity, which would allow an inherent understanding of God and morality.

The ideas of German philosopher Immanuel Kant (1724-1804) looked more appealing for the Transcendentalists. Kant, in his Theory of knowledge, considered a distinction between the world of sense and that of understanding. Kant is regarded as the first thinker who believed that God and soul are transcendent. Other German Idealists, including Fichte, Schelling were under the influence of Kant's ideas that inspired New England transcendental Philosophers. According to him, sensory experience could reveal things as they appeared, but understanding revealed them as they were. In his book, "Critique of Practical Reason" Kant expressed: "I call all knowledge transcendental which is concerned, not with objects, but with our mode of knowing objects so far as this is possible a priori" (Hart, 1995, P. 37).

Kant expressed that knowledge had several aspects including God, morality, freedom, and immortality which could not be understood by reason, but rather they were subject to intuitive understanding of man. The human mind was not the Tabula Rasa proposed by John Locke. For him, man was basically moral and obedient to God's orders. The internalization of such ideas was essentially transcendental. They transcend sensation and reason. Despite the fact that thinking about such philosophical ideas might look unusual for the modern man, an understanding of the differences between sensation (Materialism) and idealism (transcendence) was basic to Transcendental Philosophy. Transcendentalists owed much to Kant and realized the points of difference between Kant and Locke. In 1841, Ralph Waldo Emerson (2008), in his lecture entitled "The Transcendentalists" expressed:

"It is well known to most of my audience, that the Idealism of the present day acquired the name of Transcendental, from the use of that term by Immanuel Kant, of Königsberg, who replied to the skeptical philosophy of Locke, which insisted that there was nothing in the intellect which was not previously in the experience of the senses, by showing that there was a very important class of ideas, or imperative forms, which did not come by experience, but through which experience was acquired; that these were intuitions of the mind itself; and he denominated them Transcendental forms. The extraordinary profoundness and precision of that man's thinking have given vogue to his nomenclature, in Europe and America, to that extent, that whatever belongs to the class of intuitive thought is popularly called at the present day Transcendental." (P. 24). Transcendentalists used to read Locke and Kant's writings. Locke's work was a part of his Unitarian heritage and the college curriculum of the time. Some of the Transcendentalists, including Frederic Henry Hedge and Theodore Parker, were able to read Kant's writings in the original German language; while others, like Emerson and Theodor parker, used to read his works in English translation. The concepts proposed by Kant and other intuitive philosophers were also spread through the efforts of British and French writers. Samuel Taylor Coleridge, English poet- Philosopher emphasized on spirituality, intuition, and imagination was deeply under the influence of Kant, and in turn, influenced Transcendentalists. The word "Transcendent", according to Kant referred to:

"qualities that lie outside of all 'experience' that cannot be brought within the recognized formularies of thought, cannot be reached either by observation or reflection, or explained as the consequences of any discoverable antecedents". (Frothingham, 2010, P. 213).

Indian and Chinese religious teachings, in part, had impact on the mystical aspects of Transcendentalism. Despite the fact that Transcendentalism was not a philosophy in its systematic meaning of the word, some common principles could be seen shared among its followers. The idea that God is present in each person and in the nature and that intuition is the unique source of knowledge caused the emergence of a positive emphasis on individualism, self- reliance, and the rejection of traditional authority.

What Transcendentalists believed was that each person is capable to change positively and could attain divinity which means reaching a communion with God based on the reliance on their inherent goodness and reliability and faith in their own instinct. This is a sharp contrast between Calvinistic - Puritanical views which emphasized on the concept that man is inherently evil. Transcendentalists believed that every individual has a divine source within and must be free to achieve its full power. That was the reason that Transcendentalist favored reforms.

Puritanism was a religious movement the way Protestant reformation was. Puritans wished to reform England the way Calvin did in Geneva. Puritan religious doctrines were fundamentally based on Calvinism. They agreed with Calvin in his teachings, since what he preached was based on Bible and experience. In the book, "American Literature", it was expressed that there are five points of Puritan basic tenets including: 1) The supremacy of Divine Will, 2) The Depravity of Man, 3) Election, 4) Free Grace, and 5) Predestination (Crawford, 2007, P. 224).

The starting point for Puritan Theology was an emphasis on the Majesty, righteous, and sovereignty of God. God has the absolute authority and arbitrary power to create and interfere in the universe. Everything in this world is directed using His morality, due to his will. If God wills his world, it must be directed by His morality and worldly occurrence must be the consequence of His moral law. Puritans also believed in the depravity of man. For the puritans, human beings were deprived sinners unable of getting any worth in the eyes of God, this was the idea they got from the scripture, social surrounding, and a personal introspection. (Eliad, 1987, P. 103).All human beings were regarded as sinful because of Adam's fall for his wrong doing in the Garden of Heaven.

In the eyes of the Puritans, Human being was sinful and weak and thus deserved damnation. Many preachers gave a picture of themselves as hopelessly stupid, wickedly sinful, and irrecoverable damned (Crawford, 2007, P. 224). Puritans, also, believed in the concept of election which refers to the idea that Christ's sacrifice has resulted in the covenant with God to save the elected person from damnation. They also hold the idea that God" elected" or 
predestined certain persons, a small number, not all mankind by any means - to be saved ones and did this due to his mercy. What Puritans preached was that good work was fruitless in getting salvation, because it did not please God and the sinners could not save themselves. For the Puritans, people could not simply reach the salvation by taking hold of natural means provided by God, including the scripture, sacrament, and sermons of Godly preacher. The elected person could be associated with the Spirit's transforming work on their souls.

English Puritans were separated into Non-separatists and separatists following the problems they faced. The first group consisted of those who tried to continue their attempt in reforming the Church of England and keep their existence in England, while the second one consisted on those who could not manage to preserve a Calvinistic Christianity in which they believed. The name they got was for the sake of their attempt to separate from the Church of England. They wanted to have their own church free from the Roman Catholicism. The separatists immigrated to America where they thought they could make their dreams true.

The Puritans went to New England because of some religious, political, and economic reasons. The basic reason for which they emigrated to America was the avoidance of conflict with the king and finding a religious freedom to practice and spread their belief. John Winthrop, the first governor of Massachusetts Bay Colony, believed that the colonists were the first in establishing the kingdom. In 1630, he expressed that their mission in establishing the kingdom was to build a city upon the hill. This means that what they had in mind was to become a reverent congregation for others. Puritan migration to America had significant impact on the development of American literature and thought.

Puritan inheritance influenced the American character and the trend of American spirit formation. Since the puritan settlers were educated and intellectual, they contributed to the trend of education through establishing educational institutions and universities. They believed in the capability of university education in the salvation of man from the Satan. Also the Puritans gave a lot of importance to the establishing of religious freedom. For them, it was very important that the word of God be preached freely, which resulted to the emergence of the spirit of toleration in facing religious diversity. "Many scholars have noted the contribution of Puritanism to the development of democracy" (Crawford, 2007, P. 224).The Puritans also emphasized on the enforcement of the checks and balances of power.

The effect that Unitarian history has had on the religion in Europe and America has been considerable. In late 1700s, a group of Christians, who called themselves as Unitarian, separated away from New England Puritan Church of England. They rejected the traditional Christian "trinity", which expresses that there are three divine elements of God, namely, Thefather, The son (Jesus Christ), and The Holy Spirit. Unitarians also rejected the predestination, the concept that God has already decided on who is predestined for heaven or hell. They believed that everybody had the free will to work for his or her salvation.

Unitarians emphasized on a range of liberal concepts. For them, God' goodness and loving kindness, necessary for mankind to be like God and comprehend Him, and in human capacity for spiritual, moral, and intellectual improvement of high value. William Ellery (2012), in his "Unitarian Christianity", expressed: "The idea of God, sublime ... as it is, is the idea of our own spiritual nature, purified and enlarged to infinity. In ourselves are the elements of the Divinity" (Channing, P. 17).

William Ellery Channing who was a much respected preacher of his time was loved by his Unitarian fellows, and feared by the Calvinists as much. He founded The American Unitarian Association. He wrote different books, and preached sermons against all kinds of social defects including alcohol, child labor, and exploitation of women. As a very fearless and brave man, he condemned the use of force in dealing with the slave traders and holders. Once he wrote: "The North has one weapon, moral force." He spoke, gave lectures, and traveled every place he could to preach his ideas.

After three decades, another split occurred within the Unitarian Church of Boston; some even doubted the divinity of Christ. Some of the leading figures of Unitarian Church figures, including, Ralph Waldo Emerson, left the church to find a more meaningful religious life.

Transcendentalism originated from English Romanticism and German idealist philosophy, Unitarianism and Eastern religions (Ashton, 2006, P. 5). It stands on one main principle that God is both immanent and transcendent; both in the world and outside of it. (Wagenknecht, 1974, P. 145). The idea of immanence referred to "inalienable worth of man", (Frothingham, 20101, P.136).because God is within mankind, and according to the principle of transcendence God is all-encompassing. These were regarded as radical religious ideas for those who were familiar with traditional Christian theology. Transcendentalism seemed a "mass of mild opinions", the most important of all these was the concept of "God in the Soul, faith in immediate inspiration, in boundless possibility, and in unimaginable good."

Transcendentalism stood at the top of literary and aesthetic romanticism in Europe and America, which was distinguished the reaction against formalism and convention and an emphasis on human emotion, subjectivity, and inspiration. It can be said that, Transcendentalism which was inspired by English and European writers, was a type of American Romanticism. In his book "Romanticism and Transcendentalism", Jerry Phillips (2010) expressed: "All of the principles seen in European romanticism find their way into American thought, especially as these ideas come into the American conscience through the Transcendentalist writers, poets, and thinkers. Romanticism and Transcendentalism had a profound effect on the American character" (P. 27).

One important difference between Romanticism and Transcendentalism was in their view of God and His role in the lives of people. Transcendentalism was based largely on the concept That God is an internal force and every creature as 
His creation has within himself a divine spark namely, "inner light." Therefore, the final goal of human life would be to connect to that inner light; that is, something which is referred to as "over-soul"" which means that part of God which unifies all living things. On the other hand, Romanticism, in comparison, had less to do with God. For the romantic, God was an external force as opposed to the internal spark of light. The idea of "high reason" rests at the heart of Transcendentalism in which religion is seen as an individual matter of intuition or insight. Charles Mayo Ellis (1970) in his article, "Essay on Transcendentalism" expressed:

"Transcendentalism is predicated on the reality of spiritual or religious element in man, his inborn capacity to perceive truth and right, so that moral and religious truths can be proved to him with the same degree of certainty that attends mathematical demonstration" (P. 19).

Another difference between Romanticism and Transcendentalism lies in the concept of inherent goodness or internal dark side of human beings, which is very much connected to the views regarding God. Romanticism was related to the "spirit of perverseness" in human nature; and on a larger scale with the "flaw in the universe." Many Romantic works emphasize on the concept that everything may not be all correct. This directly stands opposed to the Transcendentalist view that people are ultimately good.

Transcendentalism believed that inner goodness in the spirit of man is taken for granted due to the concept of "inner light". Everybody carries a part of that goodness and God within his soul; therefore, inherent goodness is inevitable because human beings are all God. This is something which can be referred to as "Ultimate goodness beyond explanation". In Conversations with God, it's explained in more specific terms as something which the spirit comprehends deeply, but which the mind can rarely understands. Transcendentalists believed that, there was no "flaw in the universe". For them, there was only God."A central tenet of Transcendentalism was the conviction that human Beings could elevate themselves beyond their baser animal instincts, attain a higher consciousness, and take part in the spirit of the divine" (Phillips, 2010, P. 27).

Transcendentalists and Unitarians shared the concept of monotheism. According to Channing (2012): "There is One God...the Father; and that Jesus is not this One God, but his son and messenger" (P.17). For the Transcendentalists Christ was like other prophets, with the difference only in degree, not in quality. In "The Dial", Emerson (1842) expressed:

"Christ differs from other men only in degree, and the miracles he wrought differ from other men's acts, only as he differs from them. He is to other religious teachers - to Moses, Zoroaster, Socrates, and Confucius - what Shakespeare is to other poets" (P. 124).

All religious preachers had been under the inspiration of God, they revealed Godly truth bit by bit progressively, based on the needs of the time. None of them was sufficient for the all time. Emerson (2011) in a reply to a question about divinity of Christ, in his "Man Thinking" said:

"The man has never lived that can feed us ever. The human mind cannot be enshrined in a person who shall set a barrier on any one side to this unbounded, unbound able empire. It is one central fire, which flaming now out of the lips of Etna, lightens the capes of Sicily; and now, out of the throat of Vesuvius, illuminates the towers and vineyards of Naples. It is one light which beams out of thousand stars. It is one soul which illumines all men" (P. 118).

Transcendentalists became different from The Unitarians because they valued "heart" over "mind". Emerson attacked the Unitarian Church for presenting a lifeless and cold picture of Christianity; he even called them "corpse cold, an ice box" with "coldness constantly increasing". He put Jesus' miracle under question, and preferred to focus on his moral preaching. Emerson believed that individuals were able to explore truth and God without being themselves without being a member of any church or any specific religious belief. Emerson (1993) was of the idea that religion was "a disease of the intellect." A great man understands divinity in a form of a system which cannot be explained even by him; but, the immortal light cannot be limited into any system and "beam over the universe on the first morning" (P. 49). For Emerson (1993), faith depended on neither creeds nor authority: "The faith that stands on authority is not faith" (P. 49).The more a religion depends on authority, the more it has to lose. A religion can be a revelation today, as it has been throughout the history, it does not have to be a history of the things in the past. So the source of inspiration should be the present time, and not the past. God speaks to us today just as he has been speaking with the prophets during the history of mankind. God speaks through nature, which teaches how to worship, because religion and nature are related, it reflects spirituality and moral law.

Thoreau (2011) thought that religion was unacceptable because it was only a habit and obstacle to the intellect. He used to see his fellow villagers in their religious acts, as hoping "by a certain outward observance and a few prayers, and by walking in a particular straight though useless path from time to time, to save their souls." (P. 27).Religion can even be misused, as some used the bible to support Slavery. According to Thoreau ( 2011) everybody had to be universal in his religious experience and listen to all who speak about the spirituality - not only to Jesus Christ, but also to Zoroaster - and let " our Church" go by the board" (P. 143). He also emphasized on his idea that everybody is divine and can know God at any moment more than any other time and a forest is a better place to know God than a church is. Through getting close to nature, everybody can feel the divinity. In his book, "New England literary Culture", Lawrence Buell (1986) explained about Transcendentalism:

"Transcendentalism, in fact, really began as a religious movement, an attempt to substitute a Romanticized version of the mystical ideal that humankind is capable of direct experience of the holy for the Unitarian rationalist view that the 
truths of religion are arrived at by a process of empirical study and by rational inference from historical and natural evidence" (P. 146).

Transcendentalism is concerned with making individuals find meaning within themselves instead of waiting for another higher source of guidance including God or Church.

\section{LITERARY CONTEXT}

Transcendentalism rose out of a literary background in the Romantic Movement in America, Britain, and Europe. Romanticism spread in American literature between 1820 and the end of the Civil War. It was expressed not only in the works of Transcendentalists, but also their contemporaries, including James Fenimore Cooper, Edgar Allan Poe, Henry Wadsworth Longfellow, Nathaniel Hawthorne, Herman Melville, and Walt Whitman, who produced a variety of works in different genres. A part from literature, Romanticism had great effect on architecture and music.

British Romantic writers William Wordsworth, Samuel Taylor Coleridge, and Thomas Carlyle had great impact on the New England Transcendentalists. Poets Wordsworth (1770-1850) and Coleridge (1772-1834) together wrote Lyrical Ballads, the first edition of which was issued in 1798. Lyrical Ballads was the personal representation of these two great poets regarding their personal feelings. They also had used a spoken language instead of a stylized written word, and focused on both supernatural and everyday life experiences. In his Biographia Literaria (1817) and his Aides to Reflection (1825), Coleridge presented the Kantian difference between knowledge obtained through the senses, or "understanding" and the grasped intuition; or "reason" and discussed German philosophy.

Emerson was a public speaker who explored new spiritual philosophies. He assembled a group in his personal home for spiritual discussions. This group later formed the Concord School, and finally, Transcendental Club. Among its members were Bronson Alcott, Henry David Thoreau, Nathaniel Hawthorne, and Margaret Fuller as well as Theodore Parker. These persons launched the philosophy of Transcendentalism, in their neighborhood. This club functioned as a forum for maintain and nourishing new ideas and concepts in informal and open minded discussions that often revolved around one single topic.

One considerable young member of the transcendental club in Boston was Theodor Parker, a contemporary of Emerson. Parker felt deep respect for Emerson; adopted the tenets of Transcendentalism as the basic principles of his life. There was a point of difference between him and Emerson in their area of focus. Parker was an outspoken activist, whose passion was putting into practical application the theoretical ideas proposed by Emerson (Shepherd, 1986, P. 97).

Transcendentalism as the representation of Romanticism spread throughout the works of the faithful. Emerson, Thoreau, Fuller, and others published lengthy works of literature in a wide variety of genres and subjects; each of which was a representation of Romantic ideals. Transcendentalists also expressed their philosophy, concerns, and creativities through shorter pieces of writing in periodical publications that were important to the intellectual improvement of the nineteenth century. The Western messenger, which was published in Cincinnati and Louisville from 1835 to 1841 , covered some pieces of Unitarianism, Transcendentalism and German and oriental philosophies and literatures. The Western Messenger was the first magazine with a literary and religious purpose. It had literary coverage, original poetry, progressive social matters, and its "combination of liberal religion with literature, Western, and European" (McKinsey, 1973, P. 6) made it unique. As the manifesto of Transcendentalism, "The Dial”, which was edited by Emerson and Margaret Fuller and published by Elizabeth Palmer Peabody, was out between 1840 and 1844.

Transcendentalism and its specific view regarding nature has some single and especial impact on the American literature, most noticeably in the works of some great American writers, including Nathaniel Hawthorne (the Scarlet letter, 1850), Walt Whitman (Leaves of Grass, 1855) and Herman Melville (Moby- dick, 1851). Hawthorne and Melville strongly disagreed with Transcendentalists' view regarding the perfectibility of man .They believed that the man is not perfect and what they emphasized was the evil present in the world and nature. What they wrote illustrated the idea that human beings are not always moving toward truth and righteousness, beauty, and justice. They are sometimes under the temptations of Satan and give way to cruelty, injustice, and the eternal search of power and oppressiveness over their fellow men.

They believed in the concept of original sin and human tendency to evil. Critics have classified Hawthorne and his works to Romantic period or better say Dark Romantic period of American literature (Reynolds, 2001, P. 525). His works usually contain cautionary tales that inspire guilt, and sin as inherent qualities of human nature. Hawthorne was interested in some Transcendentalists' concepts like free inquiry, radicalism and contact with natural life. Nathaniel Hawthorne strongly criticized Thoreau. He believed that:

"has repudiated all regular modes of getting a living, and seems inclined to lead a sort of Indian life among civilized men- an Indian life, I mean, as respects the absence of any systematic effort for a livelihood" ( Hawthorne, 1967, P. 110).He also even criticized his writing ability: "There is one chance in a thousand that he might write a most excellent and readable book," but if he did it would be "a book of simple observation of nature, somewhat in the vein of White's History of Selborne" ( Borst, 1992, P. 95). It is worth mentioning that the main concepts of Transcendentalism which were revealed in Hawthorne's "The scarlet Letter" were the Transcendentalist doctrine of Self- Reliance and Compensation. According to the latter, every action brings its rewards and punishments with itself. The wrong doer is punished, though police never find him, because the price of wrong is the loss of innocence, fear and arrest, and or suspicion of other men. According to the principle of Self -Reliance, which emphasized on the human life in 
accordance with the nature, listening to the orders of over -soul as revealed in his inherent instincts and desires, man should free himself from his past and of a conventional society, which contains the past.

Hawthorne's "The Scarlet Letter" is full of Puritan social aspect of life. Hawthorne always wrote about man in society, rather than simply about man in nature. The whole story is a representation of a conflict between man and his society in which the role of society in maintain and controlling its members is illustrated. This romance shows the hidden sin and guilt present in the puritan society due to their intolerance. "The Scarlet Letter" illustrates the Calvinistic obsession with morality, sexual repression, guilt, confession, and spiritual salvation.

Hawthorne was not a Transcendentalist; however, he spent some period of time among them. He married to Sophia Peabody, sister of Elizabeth Palmer Peabody. He lived in Concord from 1842 till 1845, when Transcendentalist movement was at its highest vogue. Hawthorne's romances and stories, rich with symbolism and allegory, focused on the individual, explored morality, dealt with historical subjects, and examined the effect of the past upon the present.

Based on his life experiences and knowledge obtained in exotic places and at sea, Herman Melville (1819- 1891) created considerable works of writing. In his "Moby Dick" he illustrated an atmospheric, evocative, allegorical, symbolic, an exploration of good and evil state of affairs which were the embodiment of Romantic literature. Moby Dick deals with the value of life, as Melville used to them: philosophy, psychology, myths, and social norms. Moby Dick or The Whale has become Melville's most famous work and regarded as one of the greatest works of literature of all time which was dedicated to his friend Nathaniel Hawthorne (Cheevers, 2007, P. 196). The writer illustrates the most characteristic features of Transcendentalism in his novel. These can be noticed in the features of the main character, Ishmael, the narrator of the story.

Poet Walt Whitman (1819- 1892) was deeply influenced by Emerson's thoughts and works. His Leaves of Grass (1855) praised the individual and appreciated personal expression, freedom, and the understanding of the world through intuition. Despite Whitman was not considered a religious man, he was influenced by the religious philosophy of his time. While he was young, Whitman adopted his parents' belief in the Quaker leader Elias Hicks, who was of the belief that the only way to communicate with God was the inner light. Whitman poetic diction of the self was the secular equivalent of what Quaker Hicks explained about the inner light (Reynolds, 2000, P. 18).

Whitman (1995) believed that the eyesight was more powerful than other senses because it was independent from the rest of the "foreruns the identities of the spiritual world" (P. 415). Whitman engaged in three dialogues of selfawareness: the self and the physical world, the self and others, and the self and spirit. Whitman found the self first in the human body. His view was different from that of Emerson's Transcendentalism in that the physical body was as important as the soul and it is celebrated in its natural state. Whitman was deeply under the influence from Emerson, who he though helped him discover himself: "I was simmering, simmering, simmering; Emerson brought me to a boil" (Reynolds, 1995, P. 85). In 1842, Whitman had a trip to hear Emerson's lecture on poetry boosted Whitman's aspirations to be the American Bard. For Whitman, sensuality was of much more importance than that of Transcendentalists.

In 1850, he embarked on the job of writing his "Leaves of Grass", a collection of poetry he edited and completed to the end of his life ( Miller, 1962, P. 55).The book was deeply appreciated from Ralph Waldo Emerson, who wrote a praising five-page letter to Whitman and recommended the book to his friends.

\section{CONCLUSION}

Many social reform movements altered the nation, during the nineteenth century namely: The abolitionist movement, the temperance movement, and the women's suffrage movement. To the followers of Transcendentalism, slavery was inherently wrong, because it stood in the way of the spiritual development of the slaves. Transcendentalists protested against slavery in a number of different ways and even some of them played a leading role in the abolitionist movement. Apart from that, transcendental movement was active in the philosophical foreground. From the time of Plato who proposed the concept of Transcendentalism to Kant who was interesting for the Transcendentalists. Kant is regarded as the first thinker who believed that God and soul are transcendent. What Transcendentalists believed was that each person is capable to change positively and could attain divinity which means reaching a communion with God based on the reliance on their inherent goodness and reliability and faith in their own instinct.

"Transcendentalism, in fact, really began as a religious movement, an attempt to substitute a Romanticized version of the mystical ideal that humankind is capable of direct experience of the holy for the Unitarian rationalist view that the truths of religion are arrived at by a process of empirical study and by rational inference from historical and natural evidence" (Buell, 1986, P. 146).

Transcendentalism is concerned with making individuals find meaning within themselves instead of waiting for another higher source of guidance including God or Church.

Transcendentalism rose out of a literary background in the Romantic Movement in America, Britain, and Europe. It was expressed not only in the works of Transcendentalists, but also their contemporaries, including James Fenimore Cooper, Edgar Allan Poe, Henry Wadsworth Longfellow, Nathaniel Hawthorne, Herman Melville, and Walt Whitman, who produced a variety of works in different genres. Transcendentalism as the representation of Romanticism spread throughout the works of the faithful. Emerson, Thoreau, Fuller, and others published lengthy works of literature in a wide variety of genres and subjects; each of which was a representation of Romantic ideals. Transcendentalists also 
expressed their philosophy, concerns, and creativities through shorter pieces of writing in periodical publications that were important to the intellectual improvement.

Transcendentalism and its specific view regarding nature has some single and especial impact on the American literature, most noticeably in the works of some great American writers, including Nathaniel Hawthorne (the Scarlet letter, 1850), Walt Whitman (Leaves of Grass, 1855) and Herman Melville (Moby- dick, 1851). Hawthorne and Melville strongly disagreed with Transcendentalists' view regarding the perfectibility of man .They believed that the man is not perfect and what they emphasized was the evil present in the world and nature. What they wrote illustrated the idea that human beings are not always moving toward truth and righteousness, beauty, and justice.

\section{REFERENCES}

[1] Banner, L (1980). A Radical for Woman's Rights. Boston: Little, Brown and Company.

[2] Bean, J (2000). Margaret Fuller, critic: writings from the New York Tribune, 1844-1846.New York: Columbia University Press.

[3] Bergson, H (2007). Introduction to Metaphysic. Basingstoke: Palgrave Macmillan Press.

[4] Borst, R (1992). The Thoreau Log: A Documentary Life of Henry David Thoreau, 1817-1862. New York: G.K. Hall.

[5] Buell, L (1986). New England Literary Culture. New York: Cambridge University Press.

[6] Channing, W (1012). Unitarian Christianity. Charleston: Create Space Press.

[7] Cheevers, S (2007). American Bloomsbury: Louisa May Alcott, Ralph Waldo Emerson, Margaret Fuller, Nathaniel Hawthorne, and Henry David Thoreau; Their Lives, Their Loves, Their Work. New York: Simon and Schuster Press.

[8] Crawford, B (2007). American Literature. Tracy: Crawford Press. 2007. P. 224.

[9] Donald, D (1969). An Excess of Democracy: the American Civil War and the Social Process. Oxford: Clarenden Press.

[10] Eliade, M (1987). The Encyclopedia of Religion. New York: Macmillan Publishing Company.

[11] Ellis, C (1970) An Essay on Transcendentalism. Portsmouth: Greenwood Press.

[12] Emerson, R. W (2008). Nature. New York: Kindle Edition.

[13] Emerson, R. $\quad$ W. Dial $\quad$ Essays. 1842. Online works of Waldo Emerson. <http://user.xmission.com/ seldom74/emerson/transcen.html>. Accessed on 5 June, 2012.

[14] Emerson, R. W (1993). Self-Reliance and Other Essays. New York: Dover Publications.

[15] Emerson Ralph Waldo. Sermon delivered to First Unitarian Society. <http://quotes.dictionary.com/But_with_whatever_exception_it_is_still_true >. Accessed on 4 June, 2012.

[16] Emerson, R. W (2011). Smith Orren Henry. The American Scholar. Charleston: Nabu Press.

[17] Emerson, R.W (2008). The Transcendentalist. Charleston: Forgotten Books Press.

[18] Felton, R. T (2006). Journey Into the Transcendentalists' New England .Berkeley: Roaring Forties Press.

[19] Foerster, N (1962). Image of America. London: University of Notre Dame Press.

[20] Frothingham, O. B (2010).Transcendentalism in New England: A History. New York: Nabu press.

[21] Fuller, M (2009). Women in the Nineteenth Century. New York: Cornell University Library.

[22] Gross, R. Quiet War With The State; Henry David Thoreau and Civil Disobedience. Malden. // The Yale Review. V. 93. No. 4. 2005. October. P. 8.

[23] Harding, W (1990). Thoreau as Seen by His Contemporaries. New York: Dover Press.

[24] Hart, J (1995). Oxford Companion to American literature. New York: Oxford University Press.

[25] Hawthorne, N (1967). The Heart of Hawthorne's Journal. New York. Barnes \& Noble.

[26] High, B. P (1986). An Outline of American Literature. New York: Longman Inc.

[27] Kaplan, J (1980). Walt Whitman: A Life. New York: Simon and Schuster.

[28] Lindenmeyer, K (2000). The Human Tradition: Ordinary Women, Extraordinary Lives Women in American History. New York: Lanham Rowman \& Littlefield Publishers.

[29] Loving, J (1999). Walt Whitman: The Song of Himself. New York: University of California Press.

[30] McKinsey, E (1973). The Western Experiment New England Transcendentalists in the Ohio Valley. Cambridge: Harvard University Press.

[31] Miller, J (1950). Jr. Walt Whitman. New York: Twayne Publishers, Inc.

[32] Miller, P (1950). The Transcendentalists: An Anthology. Cambridge: Harvard University Press.

[33] Nichols, A. (2006). Emerson, Thoreau, the Transcendentalist Movement. Chantilly: The Teaching Company.

[34] Phillips, J (2010). Romanticism and Transcendentalism :( 1800-1860). New York. House Publications.

[35] Reynolds, D (2000). A Historical Guide to Walt Whitman. New York. Oxford University Press. 2000. P.18.

[36] Reynolds, David S. (2001). Beneath the American Renaissance: The Subversive Imagination in the Age of Emerson and Melville. Cambridge. Harvard University Press. P. 524.

[37] Reynolds, D. (1995). Walt Whitman's America: A Cultural Biography. New York: Vintage Books.

[38] Shepherd, T. (1986). Friends in High Places. Unity Village. Unity School of Christianity.

[39] Stula, N (1999). Painter of Transcendentalism, in Transient and Permanent: The Transcendentalist Movement and Its Context. Boston: Massachusetts Historical Society.

[40] Sutherland, D. (1989). The Expansion of Everyday Life: 1860 -1876. New York: Harper \& Row.

[41] Thoreau, H. D. (2011). Resistance to Civil Government. Boston: Empire Books.

[42] Thoreau, H. D. (2004). Walden: or, Life in the Woods. Boston: Shambhala Press.

[43] Wagenknecht, E (1974). Portrait of a Balanced Soul. New York: Oxford University Press.

[44] Wayne, T. K. (2006). Encyclopedia of Transcendentalism. New York: Facts on File, Inc.

[45] Whitman, W. (1959). Leaves of Grass. Boston: Houghton Mifflin Company.

[46] Wilson, L. P. (2004). Thoreau, Emerson, and Transcendentalism. New York: IDG Books Worldwide, Inc. 


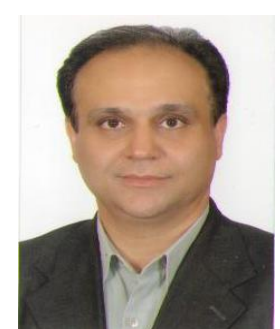

Alireza Manzari was born on $16^{\text {th }}$ September, 1966 in Mashhad, Iran. He got his high school diploma in 1986 in Humanities. His B.A. from Torbat Azad University was granted to him in 1990 in English Literature. He got his M.A. in English Teaching as a Second language from U.M. Malaysia. He is now a Ph.D. candidate at Yerevan National Academy of Science, Armenia. His work is on Transcendentalism in Henry David Thoreau's works.

He has been working as an educational administrator and manager in Azad University of Mashhad since 1992. He also has been teaching many general and Specific English language courses in Azad university of Mashhad, Iran. He has published the following articles: 1- The Role of nature in Transcendentalism. Yerevan, Armenia, Yerevan State University, 2011. 2- Henry Thoreau and Anti slavery Movement in the United states in the middle nineteen century. Yerevan, Armenia, Yerevan State University, 2011. 3- Margret Fuller, as an American Feminist in Transcendentalism. Yerevan, Armenia, Yerevan State University, 2011. 